\title{
New Sources of Resistance to Cadophora gregata f. sp. adzukicola and Fusarium oxysporum f. sp. adzukicola in Vigna spp.
}

Norio Kondo, Research Faculty of Agriculture, Hokkaido University, Sapporo 060-8589, Japan; and Norihiko Tomooka, National Institute of Agrobiological Sciences, Tsukuba 305-0862, Japan

\begin{abstract}
Kondo, N., and Tomooka, N. 2012. New sources of resistance to Cadophora gregata f. sp. adzukicola and Fusarium oxysporum f. sp. adzukicola in Vigna spp. Plant Dis. 96:562-568.

Adzuki bean brown stem rot (BSR), caused by Cadophora gregata $\mathrm{f}$. sp. adzukicola, and adzuki bean Fusarium wilt (AFW), caused by Fusarium oxysporum f. sp. adzukicola, are serious problems in Hokkaido, Japan, and have been managed using cultivars with multiple resistance. However, a limited number of adzuki bean varieties are resistant to these pathogens because of the frequent appearance of new races; thus, new sources of resistance have been sought in related $\mathrm{Vi}$ gna spp., particularly in the section Angulares to which adzuki bean belongs. An analysis of selected Vigna accessions (JP81231 to JP235420) conserved in the Genebank of the National Institute of

Agrobiological Sciences, Tsukuba, Japan, revealed wide variation in resistance spectra and resistance combinations, and eight disease response groups (A to $\mathrm{H}$ ) were identified. Four of eight were newly detected response groups, suggesting the existence of novel resistance genes. Of 252 accessions from 26 species, 28 accessions in Vigna angularis var. nipponensis, V. hirtella, V. minima, and V. tenuicaulis (section Angulares) from group D, which were cross-compatible with adzuki bean, are expected to be potential sources of multiple resistance genes. They were resistant to all races of BSR and AFW pathogens examined.
\end{abstract}

Brown stem rot (BSR) of domesticated adzuki bean (Vigna angularis var. angularis), caused by the soilborne fungus Cadophora gregata (syn. Phialophora gregata) f. sp. adzukicola $(8,11)$, is a serious problem in Hokkaido, Japan (2). Adzuki bean Fusarium wilt (AFW), caused by Fusarium oxysporum f. sp. adzukicola (10), another soilborne fungus, is often observed in the western part of Hokkaido $(2,14)$. Both diseases are characterized by wilting and a reddish-brown discoloration of vascular and pith tissues in the stem and petiole that often occurs in conjunction with leaf chlorosis or necrosis $(14,18)$. AFW is an early-season disease usually appearing in early July, whereas BSR occurs from late August to early September. In both cases, the pathogen invades the root tissues of young plants, then spreads upward to the vascular and pith tissues via mycelia and conidia $(14,18)$, leading to wilting in susceptible plants.

The multiple-resistant adzuki bean 'Kita-no-otome' (registered in 1996) and 'Syumari' (registered in 2003) have contributed greatly to the control of both diseases, especially AFW $(4,5,14)$. However, race 2 of $C$. gregata f. sp. adzukicola, which is virulent on both cultivars, was discovered in $1995(12,13)$. To find a new source of resistance to race 2, Fujita et al. (3) screened 236 cultivated and 33 wild adzuki bean plants and selected several cultivated (e.g., Acc259) and wild (V. angularis var. nipponensis; e.g., Acc2515) adzuki bean accessions resistant to both races 1 and 2 (3). However, Acc259 (a local cultivar from Ehime prefecture, Shikoku, Japan), one of the accessions used as a resistance gene donor for races 1 and 2, became completely susceptible to a new race (designated race 3) after continuous field cultivation at the Tokachi Agricultural Experiment Station (TAES) in Memuro, Hokkaido, Japan (15). As the number of designated races has increased in Hokkaido, the need to find additional sources of resistance and to incorporate multiple sources of resistance into commercial culti-

Corresponding author: N. Kondo,

E-mail: norikon@res.agr.hokudai.ac.jp

Accepted for publication 13 November 2011.

http://dx.doi.org/10.1094/PDIS-06-11-0463

(C) 2012 The American Phytopathological Society vars has become essential. Kondo et al. (16) screened a total of 67 accessions using race 3 of BSR and found 39 resistant accessions. However, only two accessions showed resistance to all three races of BSR and AFW (16): Akamame (cultivated accession) and Acc2515 (a wild accession collected in Ishikawa prefecture, Japan).

The work of Fujita et al. (3) and Kondo et al. (16) suggested that wild relatives of adzuki bean have strong potential as novel sources of resistance; therefore, further screening of wild species belonging to the genus Vigna was conducted in the present study. From hybridization studies in domesticated adzuki bean, several wild Vigna spp. in the section Angulares were revealed to be cross-compatible and were classified as the primary gene pool of cultivated adzuki bean (23) based on the concept of Harlan and De Wet (7). This Vigna gene pool is expected to contribute to the development of resistant cultivars of adzuki bean. The purpose of this study was to identify new sources of resistance to $C$. gregata f. sp. adzukicola and F. oxysporum f. sp. adzukicola in the wild Vigna gene pool.

\section{Materials and Methods}

Plant materials. The Vigna spp. germplasm examined in this study consisted of 252 accessions from 26 species (JP accession numbers JP81231 to JP235420) conserved in the Genebank of the National Institute of Agrobiological Sciences (NIAS Genebank) in Tsukuba, Japan (Table 1). This Vigna spp. collection includes three subgenera and six sections (i.e., subgenus Ceratotropis [sections Angulares, Ceratotropis, and Aconitifoliae], subgenus Vigna [sections Catiang and Vigna], and subgenus Plectotropis [section Plectotropis]; 23,24). In the collection, seven species (Table 1, bold) in the section Angulares are cross-compatible with adzuki bean; therefore, a large number of accessions were tested for resistance. Four cultivars and lines of adzuki bean or wild adzuki bean conserved in the TAES ('Erimo-shozu', 'Kita-no-otome', Acc259, and Acc2515) were used as standards to represent disease reaction groups (16). Seedlings were grown in the greenhouse in plastic containers ( 15 by 20 by $5 \mathrm{~cm}$ ) containing sterilized vermiculite for 10 to 14 days to fully expand their primary leaves. The roots were then washed gently with running tap water before inoculation with the pathogens. Greenhouse temperatures were a minimum of $15^{\circ} \mathrm{C}$ at night and a maximum of $32^{\circ} \mathrm{C}$ during daytime.

Fungal isolates and preparation of the inocula. The inoculations were carried out according to Kondo et al. (16). The follow- 
ing isolates of C. gregata f. sp. adzukicola were used: T96-1 (race 1, deposited as MAFF 241056 in the NIAS Genebank), T96-5 (race 2, MAFF 241057), and T650 (race 3, MAFF 241055; 16). Inocula for $C$. gregata were produced in liquid V8 juice medium (200 $\mathrm{ml}$ of $\mathrm{V} 8$ juice containing $2 \mathrm{~g}$ of $\mathrm{CaCO}_{3}$ was centrifuged at $1,400 \times g$ for $15 \mathrm{~min}$ and the supernatant was diluted to 1 liter with distilled water) at $25^{\circ} \mathrm{C}$ on a reciprocal shaker (TB-128; Takasaki Scientific Instrument, Kawaguchi, Japan) at 120 oscillations/min. After 3 weeks, mycelia and bud cells were collected by filtering through filter paper (Whatman number 1), washed in distilled wa- ter, and centrifuged. The fungal pellets were homogenized in distilled water with a homogenizer $(10,000 \mathrm{rpm}$ for $3 \mathrm{~min}$; AN-5, Shin-nihonseiki, Tokyo). The concentration of mycelial fragments and bud cells was determined using a hemocytometer; mycelial fragments of all sizes were included in the counts. Homogenized cultures were then diluted with distilled water to a concentration of $10^{7}$ propagules/ml. Isolate $96-3 \mathrm{~K} 2$ (MAFF 241054) of $F$. oxysporum f. sp. adzukicola, a race 3 virulent on many varieties (14), was also used. The inoculum was produced in potato sucrose broth medium (Difco, Lawrence, KS) with $2 \%$ yeast extract (Difco) at

Table 1. Vigna plant accessions in disease response groups representing resistance or susceptibility to Cadophora gregata f. sp. adzukicola and Fusarium oxysporum f. sp. adzukicola

\begin{tabular}{|c|c|c|c|c|c|c|c|c|c|}
\hline \multirow[b]{2}{*}{ Accessions $^{\mathrm{y}}$} & \multirow[b]{2}{*}{ Total } & \multicolumn{8}{|c|}{ Disease response group (reaction to each pathogen) ${ }^{x}$} \\
\hline & & $\mathbf{A}(\mathbf{S}, \mathbf{S}, \mathbf{S}, \mathbf{S})$ & $\mathbf{B}(\mathbf{R}, \mathbf{S}, \mathbf{R}, \mathbf{R})$ & $\mathbf{C}(\mathbf{R}, \mathbf{R}, \mathbf{S}, \mathbf{R})$ & $\mathrm{D}(\mathbf{R}, \mathbf{R}, \mathbf{R}, \mathbf{R})$ & $\mathbf{E}(\mathbf{S}, \mathbf{S}, \mathbf{S}, \mathbf{R})$ & $\mathbf{F}(\mathbf{R}, \mathbf{S}, \mathbf{S}, \mathbf{R})$ & G $(\mathbf{R}, \mathbf{S}, \mathbf{R}, \mathbf{S})$ & $\mathbf{H}(\mathbf{R}, \mathbf{R}, \mathbf{R}, \mathbf{S})$ \\
\hline \multicolumn{10}{|l|}{ Ceratotropis } \\
\hline \multicolumn{10}{|l|}{ Angulares } \\
\hline Vigna angularis ${ }^{\mathrm{z}}$ & 80 & 4 & 38 & 14 & 12 & 9 & $\ldots$ & 1 & 2 \\
\hline V. hirtella & 35 & $\ldots$ & 2 & 3 & 10 & 19 & 1 & $\ldots$ & $\ldots$ \\
\hline V. minima & 21 & 2 & 1 & 3 & 2 & 13 & $\ldots$ & $\ldots$ & $\ldots$ \\
\hline V. nakashimae & 25 & $\ldots$ & $\ldots$ & 5 & $\ldots$ & 16 & 4 & $\ldots$ & $\ldots$ \\
\hline V. nepalensis & 6 & $\ldots$ & $\ldots$ & $\ldots$ & $\ldots$ & 6 & $\ldots$ & $\ldots$ & $\ldots$ \\
\hline V. riukiuensis & 24 & $\ldots$ & $\ldots$ & $\ldots$ & $\ldots$ & 24 & $\cdots$ & $\ldots$ & $\cdots$ \\
\hline V. tenuicaulis & 30 & 2 & 3 & $\ldots$ & 4 & 20 & 1 & $\ldots$ & $\ldots$ \\
\hline V. dalzelliana & 1 & $\ldots$ & $\ldots$ & $\ldots$ & $\ldots$ & 1 & $\ldots$ & $\ldots$ & $\ldots$ \\
\hline V. exilis & 2 & $\ldots$ & $\ldots$ & $\ldots$ & $\ldots$ & 2 & $\ldots$ & $\ldots$ & $\ldots$ \\
\hline V. glabrescens & 1 & $\ldots$ & $\ldots$ & $\ldots$ & 1 & $\ldots$ & $\ldots$ & $\ldots$ & $\ldots$ \\
\hline V. reflexo-pilosa & 1 & $\ldots$ & $\ldots$ & $\ldots$ & $\ldots$ & $\ldots$ & 1 & $\ldots$ & $\ldots$ \\
\hline V. trinervia & 1 & $\ldots$ & $\ldots$ & $\ldots$ & $\ldots$ & $\ldots$ & 1 & $\ldots$ & $\ldots$ \\
\hline V. umbellata & 5 & $\ldots$ & $\ldots$ & $\ldots$ & $\ldots$ & 4 & 1 & $\ldots$ & $\ldots$ \\
\hline Vigna sp. (JP210811) & 1 & $\ldots$ & $\ldots$ & $\ldots$ & $\ldots$ & 1 & $\ldots$ & $\ldots$ & $\ldots$ \\
\hline \multicolumn{10}{|l|}{ Ceratotropis } \\
\hline V. grandiflora & 1 & $\ldots$ & $\ldots$ & $\ldots$ & $\ldots$ & 1 & $\ldots$ & $\ldots$ & $\ldots$ \\
\hline$V$. mungo & 2 & $\ldots$ & $\ldots$ & $\ldots$ & $\ldots$ & 2 & $\ldots$ & $\ldots$ & $\ldots$ \\
\hline V. radiata & 2 & $\ldots$ & $\ldots$ & $\ldots$ & $\ldots$ & 2 & $\ldots$ & $\ldots$ & $\ldots$ \\
\hline V. subramaniana & 3 & $\ldots$ & $\ldots$ & $\ldots$ & $\ldots$ & 3 & $\ldots$ & $\ldots$ & $\ldots$ \\
\hline Vigna sp. (JP235420) & 1 & $\ldots$ & $\ldots$ & $\ldots$ & $\ldots$ & 1 & $\ldots$ & $\ldots$ & $\ldots$ \\
\hline Aconitifoliae & & & & $\ldots$ & $\ldots$ & & & & \\
\hline V. aconitifolia & 1 & $\ldots$ & $\ldots$ & & & 1 & $\ldots$ & $\ldots$ & $\ldots$ \\
\hline V. aridicola & 3 & $\ldots$ & $\ldots$ & $\ldots$ & $\ldots$ & 2 & 1 & $\ldots$ & $\ldots$ \\
\hline V. stipulacea & 1 & $\ldots$ & $\ldots$ & $\ldots$ & $\ldots$ & 1 & $\ldots$ & $\ldots$ & $\ldots$ \\
\hline V. trilobata & 1 & $\ldots$ & $\ldots$ & $\ldots$ & $\ldots$ & 1 & $\ldots$ & $\ldots$ & $\ldots$ \\
\hline \multicolumn{10}{|l|}{ Plectotropis } \\
\hline V. vexillata & 1 & $\ldots$ & $\ldots$ & $\ldots$ & 1 & $\ldots$ & $\ldots$ & $\ldots$ & $\ldots$ \\
\hline \multicolumn{10}{|l|}{ Vigna } \\
\hline \multicolumn{10}{|l|}{ Vigna } \\
\hline V. luteola & 1 & $\ldots$ & $\ldots$ & $\ldots$ & $\ldots$ & 1 & $\ldots$ & $\ldots$ & $\ldots$ \\
\hline Catiang & & & & & & & $\ldots$ & & \\
\hline V. unguiculata & 2 & $\ldots$ & $\ldots$ & 1 & & 1 & $\ldots$ & $\ldots$ & $\ldots$ \\
\hline Total & 252 & 8 & 44 & 26 & 30 & 131 & 10 & 1 & 2 \\
\hline
\end{tabular}

${ }^{x}$ Disease response groups E-H are newly identified groups. Groups A-D were designated in Kondo et al. (16). Reaction $(\mathrm{R}=$ resistant and $\mathrm{S}=$ susceptible) are shown to $C$. gregata f. sp. adzukicola race 1, race 2, race 3, and $F$. oxysporum f. sp. adzukicola race 3, respectively.

y Subgenus, section, species. Species shown in bold are cross compatible with domesticated adzuki bean (V. angularis var. angularis).

${ }^{\mathrm{z}}$ V. angularis var. nipponensis.

Table 2. Group designation of Vigna spp. based on differential reactions to races of Cadophora gregata f. sp. adzukicola, cause of adzuki bean brown stem rot, and Fusarium oxysporum f. sp. adzukicola, cause of adzuki bean Fusarium wilt

\begin{tabular}{|c|c|c|c|c|c|c|}
\hline \multirow[b]{3}{*}{ Group } & \multirow[b]{3}{*}{ Differential cultivar or line } & \multicolumn{4}{|c|}{ Reaction $^{y}$} & \multirow[b]{3}{*}{ Number of Vigna spp. } \\
\hline & & \multicolumn{3}{|c|}{ C. gregata f. sp. adzukicola } & \multirow{2}{*}{$\begin{array}{c}\text { F. oxysporum f. sp. adzukicola } \\
\text { Race } 3\end{array}$} & \\
\hline & & Race 1 & Race 2 & Race 3 & & \\
\hline A & Erimo-shozu & $S$ & $\mathrm{~S}$ & $\mathrm{~S}$ & $\mathrm{~S}$ & 3 \\
\hline B & Kita-no-otome & $\mathrm{R}$ & $\mathrm{S}$ & $\mathrm{R}$ & $\mathrm{R}$ & 4 \\
\hline $\mathrm{C}$ & Acc259 & $\mathrm{R}$ & $\mathrm{R}$ & $\mathrm{S}$ & $\mathrm{R}$ & 5 \\
\hline $\mathrm{D}$ & Acc 2515 & $\mathrm{R}$ & $\mathrm{R}$ & $\mathrm{R}$ & $\mathrm{R}$ & 6 \\
\hline $\mathrm{E}$ & $\ldots$ & $\mathrm{S}$ & $\mathrm{S}$ & $\mathrm{S}$ & $\mathrm{R}$ & $22^{z}$ \\
\hline $\mathrm{F}$ & $\ldots$ & $\mathrm{R}$ & $\mathrm{S}$ & $\mathrm{S}$ & $\mathrm{R}$ & 7 \\
\hline G & $\ldots$ & $\mathrm{R}$ & $\mathrm{S}$ & $\mathrm{R}$ & $\mathrm{S}$ & 1 \\
\hline $\mathrm{H}$ & $\ldots$ & $\mathrm{R}$ & $\mathrm{R}$ & $\mathrm{R}$ & $\mathrm{S}$ & 1 \\
\hline
\end{tabular}

${ }^{\mathrm{y}} \mathrm{R}=$ resistant and $\mathrm{S}=$ susceptible.

${ }^{\mathrm{z}}$ Two unidentified species are included. 
$25^{\circ} \mathrm{C}$ on a reciprocal shaker at 120 oscillations/min. After 5 days of incubation, bud cells were collected by centrifugation at $1,400 \times$ $g$ for $10 \mathrm{~min}$, washed in distilled water, and centrifuged. The concentration was adjusted to $10^{6}$ bud cells $/ \mathrm{ml}$ in distilled water using a hemocytometer.

Screening for resistance. The roots of five to eight seedlings of each accession and adzuki bean cultivar, depending upon the seed numbers provided, were soaked in a suspension $(50 \mathrm{ml})$ of each inoculum for $12 \mathrm{~h}$. Two to four seedlings were then placed in each
2- to 3-cm-deep depression in sterilized potting soil (1:1 [ $\mathrm{vol} / \mathrm{vol}]$ vermiculite/Pot-ace; Katakura Chikkarin K. K., Tokyo) in plastic pots (12 cm in diameter) with two replicates. The remaining inoculum was then poured over the roots of the seedlings to maximize coverage, and the roots were covered with sterilized potting soil. All tests were conducted at least twice in all combinations and the data were combined. The nighttime low and daytime high temperatures in the greenhouse during testing were 15 and $32^{\circ} \mathrm{C}$, respectively. The plants received supplemental lighting from

Table 3. Vigna spp., geographic sources, and accession numbers in disease response groups representing resistance or susceptibility to Cadophora gregata f. sp. adzukicola and Fusarium oxysporum f. sp. adzukicola

\begin{tabular}{|c|c|c|c|c|c|c|c|c|}
\hline Group $^{y}$ & Subgenus & Section, species & Source & & Acc & on (JP nt & ber $)^{\mathbf{z}}$ & \\
\hline A & Ceratotropis & Angulares & & & & & & \\
\hline & & Vigna angularis var. nipponensis & Honsyu Island, Japan & 87907 & 201464 & 211827 & & \\
\hline & & & Kyusyu Island, Japan & 225143 & & & & \\
\hline & & V. minima & Laos & 222402 & & & & \\
\hline & & & Papua New Guinea & 226877 & & & & \\
\hline & & V. tenuicaulis & Myanmar & 211875 & 217452 & & & \\
\hline B & Ceratotropis & Angulares & & & & & & \\
\hline & & V. angularis var. nipponensis & Honsyu Island, Japan & 87896 & 87898 & 87908 & 87909 & 87919 \\
\hline & & & & 90832 & 90837 & 90842 & 90843 & 90844 \\
\hline & & & & 90845 & 90846 & 90857 & 90860 & 90861 \\
\hline & & & & 90863 & 90866 & 90869 & 110658 & 110659 \\
\hline & & & & 201458 & 201461 & 201462 & 201466 & 211839 \\
\hline & & & & 211840 & 211844 & 225126 & 225132 & 225137 \\
\hline & & & Shikoku Island, Japan & 81646 & 110690 & 110691 & 110693 & 110694 \\
\hline & & & Kyusyu Island, Japan & 110676 & 110680 & & & \\
\hline & & & Myanmar & 226056 & & & & \\
\hline & & V. hirtella & Myanmar & 210805 & & & & \\
\hline & & & Laos & 220137 & & & & \\
\hline & & V. minima & Laos & 224430 & & & & \\
\hline & & V. tenuicaulis & Myanmar & 217444 & 217476 & 217519 & & \\
\hline $\mathrm{C}$ & Ceratotropis & Angulares & & & & & & \\
\hline & & V. angularis var. nipponensis & Honsyu Island, Japan & 87905 & 87906 & 87913 & 87914 & 87917 \\
\hline & & & & 87918 & 90833 & 90834 & 90835 & 91231 \\
\hline & & & & 201457 & 225140 & & & \\
\hline & & & Kyusyu Island, Japan & 110670 & 110679 & & & \\
\hline & & V. hirtella & Laos & 224435 & 224436 & 226680 & & \\
\hline & & V. minima & Thailand & 205888 & & & & \\
\hline & & & Myanmar & 210806 & & & & \\
\hline & & & Laos & 220141 & & & & \\
\hline & & V. nakashimae & South Korea & 212329 & 212333 & 212339 & 212340 & 212349 \\
\hline & Vigna & Catiang & & & & & & \\
\hline & & V. unguiculata & Sri Lanka & 81610 & & & & \\
\hline $\mathrm{D}$ & Ceratotropis & Angulares & & & & & & \\
\hline & & V. angularis var. nipponensis & Honsyu Island, Japan & 87910 & 90836 & 90849 & 90850 & 90856 \\
\hline & & & & 107861 & 110662 & 201465 & & \\
\hline & & & Kyusyu Island, Japan & 110674 & & & & \\
\hline & & & Myanmar & 217478 & 217479 & 217480 & & \\
\hline & & V. hirtella & Thailand & 202274 & & & & \\
\hline & & & Myanmar & 217447 & & & & \\
\hline & & & Sri Lanka & 218935 & & & & \\
\hline & & & Laos & 220133 & 220134 & 220135 & 224426 & 224432 \\
\hline & & & & 224443 & 226687 & & & \\
\hline & & V. glabrescens & Philippine & 109684 & & & & \\
\hline & & V. minima & Laos & 220136 & 220139 & & & \\
\hline & & V. tenuicaulis & Thailand & 109682 & & & & \\
\hline & & & Myanmar & 217502 & & & & \\
\hline & & & Laos & 226649 & 226682 & & & \\
\hline & Plectotropis & Plectotropis & & & & & & \\
\hline & & V. vexillata & Papua New Guinea & 230747 & & & & \\
\hline E & Ceratotropis & Angulares & & & & & & \\
\hline & & V. angularis var. nipponensis & Honsyu Island, Japan & 90855 & 90862 & 201456 & & \\
\hline & & & Kyusyu Island, Japan & 110675 & 110682 & & & \\
\hline & & & Shikoku Island, Japan & 110686 & & & & \\
\hline & & & India & 110827 & & & & \\
\hline & & & & & & & ontinuec & next page) \\
\hline
\end{tabular}

\footnotetext{
${ }^{y}$ A, susceptible to all pathogens tested; B, susceptible to C. gregata f. sp. adzukicola race 2 but resistant to the other pathogens; C, susceptible to $C$. gregata f. sp. adzukicola race 3 but resistant to the other pathogens; D, resistant to all pathogens tested; E, resistant to F. oxysporum f. sp. adzukicola race 3 but susceptible to the other pathogens; F, susceptible to $C$. gregata f. sp. adzukicola races 2 and 3 but resistant to $C$. gregata f. sp. adzukicola race 1 and $F$. oxysporum f. sp. adzukicola race 3; G, susceptible to C. gregata f. sp. adzukicola race 2 and F. oxysporum f. sp. adzukicola race 3 but resistant to C. gregata f. sp. adzukicola races 1 and 3; and $\mathrm{H}$, susceptible to F. oxysporum f. sp. adzukicola race 3 but resistant to the other pathogens.

${ }^{\mathrm{z}} \mathrm{JP}=$ Japan number identifying accessions used in the Genebank of the National Institute of Agrobiological Sciences. Numbers in bold letters indicate domesticated accession.
} 
metal halide sodium lamps $(400 \mathrm{~W})$ to maintain a 16 -h photoperiod.

The disease severity of BSR (3) was assessed 8 weeks after inoculation as the mean disease severity index (DSI), where $0=$ no symptoms, 1 = slight vascular discoloration without foliar symptoms, 2 = foliar symptoms or severe vascular discoloration (above the first node or in the petioles), and $3=$ death. Plants with DSI $<$ 0.5 were rated resistant (R), plants with DSI $\geq 0.5$ to $<1.0$ were regarded as intermediate (I), and plants with DSI $\geq 1.0$ were considered susceptible (S). To evaluate AFW (14), we scored the reactions of individual plants 8 weeks after inoculation according to a disease severity rating (DSR) of 1 to $10^{3}$, where $1=$ healthy, no external symptoms, and no vascular discoloration; $10=$ plants showing vascular discoloration but no external symptoms; $10^{2}=$ plants showing leaf necrosis or stunting or wilting; and $10^{3}=$ dead plants. The DSI was calculated using the following formula: DSI = $\log _{10}$ [mean (DSR)]. Plants with DSI $\leq 1.0$ were rated resistant $(\mathrm{R})$, whereas plants with DSI $>1.0$ were considered susceptible $(\mathrm{S})$.

Table 3. (continued from preceding page)

\begin{tabular}{|c|c|c|c|c|c|c|c|c|}
\hline \multirow[t]{2}{*}{ Group $^{y}$} & \multirow[t]{2}{*}{ Subgenus } & \multirow[t]{2}{*}{ Section, species } & \multirow{2}{*}{$\begin{array}{r}\text { Source } \\
\text { Myanmar }\end{array}$} & \multicolumn{5}{|c|}{ Accession $(\text { JP number })^{\mathrm{z}}$} \\
\hline & & & & 217477 & 217481 & & & \\
\hline & & V. dalzelliana & India & 235419 & & & & \\
\hline & & V. exilis & Thailand & 205884 & 210684 & & & \\
\hline & & V. hirtella & Thailand & 108551 & 108558 & 108562 & 109681 & 110839 \\
\hline & & & Myanmar & 210823 & 211876 & 217435 & 217451 & 217491 \\
\hline & & & Laos & 220130 & 220131 & 224442 & 226635 & 226637 \\
\hline & & & & 226663 & 226669 & 226679 & & \\
\hline & & $V$. minima & Thailand & 107869 & 108129 & 205890 & 205891 & 210655 \\
\hline & & & & 210669 & 210683 & & & \\
\hline & & & Indonesia & 202289 & 218938 & & & \\
\hline & & & Myanmar & 210821 & 210824 & & & \\
\hline & & & Laos & 220140 & 220142 & & & \\
\hline & & V. nakashimae & South Korea & 81231 & 212325 & 212326 & 212327 & 212328 \\
\hline & & & & 212331 & 212334 & 212335 & 212336 & 212338 \\
\hline & & & & 212345 & 212346 & 212348 & 212352 & 212353 \\
\hline & & & Kyusyu Island, Japan & 107879 & & & & \\
\hline & & V. nepalensis & Nepal & 107881 & 109687 & 109689 & & \\
\hline & & & India & 110826 & 110827 & & & \\
\hline & & & Bhutan & 109688 & & & & \\
\hline & & V. riukiuensis & Taiwan, China & 107884 & & & & \\
\hline & & & Ryukyu Islands, Japan & 108810 & 201442 & 201446 & 201476 & 201477 \\
\hline & & & & 201479 & 201482 & 201484 & 201490 & 201495 \\
\hline & & & & 201498 & 201499 & 201500 & 201502 & 201503 \\
\hline & & & & 201508 & 201514 & 201521 & 201522 & 201526 \\
\hline & & & & 201532 & 201533 & 201542 & & \\
\hline & & V. tenuicaulis & Thailand & 108552 & 109683 & 205883 & 210671 & \\
\hline & & & Myanmar & 210795 & 210807 & 210808 & 210818 & 217448 \\
\hline & & & & 217453 & 217465 & 217471 & 217475 & 217476 \\
\hline & & & & 217486 & 217496 & 217497 & 217519 & 227438 \\
\hline & & & Laos & 224441 & & & & \\
\hline & & V. umbellata & Thailand & 109675 & 210639 & 210644 & & \\
\hline & & & India & 99485 & & & & \\
\hline & & Vigna sp. & Myanmar & 210811 & & & & \\
\hline & Ceratotropis & Ceratotropis & & & & & & \\
\hline & & V. grandiflora & Thailand & 107862 & & & & \\
\hline & & V. mungo var. silvestris & India & 107874 & & & & \\
\hline & & V. mungo var. mungo & Thailand & 109668 & & & & \\
\hline & & V. radiata var. sublobata & Madagaskal & 107877 & & & & \\
\hline & & V. radiata var. radiata & Thailand & 110830 & & & & \\
\hline & & V. subramaniana & India & 110836 & 229278 & 229284 & & \\
\hline & & Vigna sp. & India & 235420 & & & & \\
\hline & & Acontifoliae & & & & & & \\
\hline & & V. aconitifolia & Pakistan & 104332 & & & & \\
\hline & & V. aridicola & Sri Lanka & 205894 & 207977 & & & \\
\hline & & V. stipulacea & Sri Lanka & 205892 & & & & \\
\hline & & V. trilobata & Sri Lanka & 205895 & & & & \\
\hline & Vigna & Catiang & & & & & & \\
\hline & & V. unguiculata & Mali & 89083 & & & & \\
\hline & & Vigna & & & & & & \\
\hline & & V. luteola & Papua New Guinea & 230741 & & & & \\
\hline \multirow[t]{9}{*}{$\mathrm{F}$} & Ceratotropis & Angulares & & & & & & \\
\hline & & V. hirtella & Laos & 220137 & & & & \\
\hline & & V. nakashimae & South Korea & 212343 & 212344 & 212350 & 212351 & \\
\hline & & V. reflexo-pilosa & Malaysia & 108867 & & & & \\
\hline & & V. tenuicaulis & Myanmar & 217448 & & & & \\
\hline & & V. trinervia & Malaysia & 108840 & & & & \\
\hline & & V. umbellata & Myanmar & 217439 & & & & \\
\hline & & Acontifoliae & & & & & & \\
\hline & & V. aridicola & Sri Lanka & 205896 & & & & \\
\hline \multirow[t]{2}{*}{ G } & Ceratotropis & Angulares & & & & & & \\
\hline & & V. angularis var. nipponensis & Laos & 226665 & & & & \\
\hline \multirow[t]{2}{*}{$\mathrm{H}$} & Ceratotropis & Angulares & & & & & & \\
\hline & & V. angularis var. nipponensis & Laos & 226667 & 226676 & & & \\
\hline
\end{tabular}




\section{Results}

In all trials, the varieties of adzuki bean that were used as controls showed resistant or susceptible reactions to each pathogen (data not shown), as was demonstrated previously (16). Most of accessions showed clear and identical responses over the two trials. However, some accessions had reactions that differed between trials. For 15 accessions of $V$. angularis var. nipponensis, 20 of $V$. tenuicaulis, 1 of $V$. minima, and 3 of $V$. nepalensis, an additional trial was conducted to confirm the disease response. However, no intermediate evaluation was shown in the study. Consequently, eight disease response groups were created for 252 accessions examined from 26 species of Vigna, including 2 unidentified species (Tables 1 and 2): A, susceptible to all pathogens tested; B, susceptible to BSR race 2 but resistant to the other pathogens; C, susceptible to BSR race 3 but resistant to the other pathogens; D, resistant to all pathogens tested; E, resistant to AFW race 3 but susceptible to the other pathogens; F, susceptible to BSR races 2 and 3 but resistant to BSR race 1 and AFW race 3; G, susceptible to $\mathrm{BSR}$ race 2 and AFW race 3 but resistant to BSR races 1 and 3 ; and $\mathrm{H}$, susceptible to AFW race 3 but resistant to the other pathogens. Of the eight groups, E, F, G, and $\mathrm{H}$ were newly recognized in the present study; groups $\mathrm{A}, \mathrm{B}, \mathrm{C}$, and $\mathrm{D}$ were described previously (16).

Of the 26 Vigna spp. examined, 22 species, including 2 unidentified species, were placed in group E (Table 2), which contained the largest number of accessions (131 accessions), followed by groups
B (44 accessions), D (30 accessions), C (26 accessions), F (10 accessions), A (8 accessions), H ( 2 accessions), and G (1 accession) (Table 1). Accession numbers in each disease response group and the geographic source of the accession are shown in Table 3. Within the subgenus Ceratotropis, accessions belonging to the sections Ceratotropis and Aconitifoliae were mostly restricted to group $\mathrm{E}$, except for an accession of $V$. aridicola in the section Aconitifoliae belonging to group F. Contrary to previous reports $(11,12,15)$, two accessions of $V$. unguiculata were susceptible to $C$. gregata f. sp. adzukicola and were classified into group C or E.

$V$. angularis var. nipponensis, V. hirtella, V. minima, V. nakashimae, and $V$. tenuicaulis in the section Angulares, closely related and cross-compatible with adzuki bean, were largely differentiated into a variety of response groups $(n=7,5,5,3$, and 5 groups, respectively; Table 1). In particular, accessions of wild adzuki bean (V. angularis var. nipponensis) were broadly distributed throughout all of the groups except group F. The geographic distribution of five response groups for $V$. angularis var. nipponensis collected from Japan is shown in Figure 1. There was no clear geographic limitation to the range of wild adzuki bean collections, except accessions in group $\mathrm{E}$, which were found only in southwestern Japan.

In contrast, $V$. nepalensis (6 accessions) and V. riukiuensis (24 accessions) in the section Angulares did not show a diverse reaction and were restricted to group E. The accessions of $V$. angularis var. nipponensis in group $\mathrm{D}$, which is a potential source of multiple resistance genes for the development of new adzuki bean cultivars,

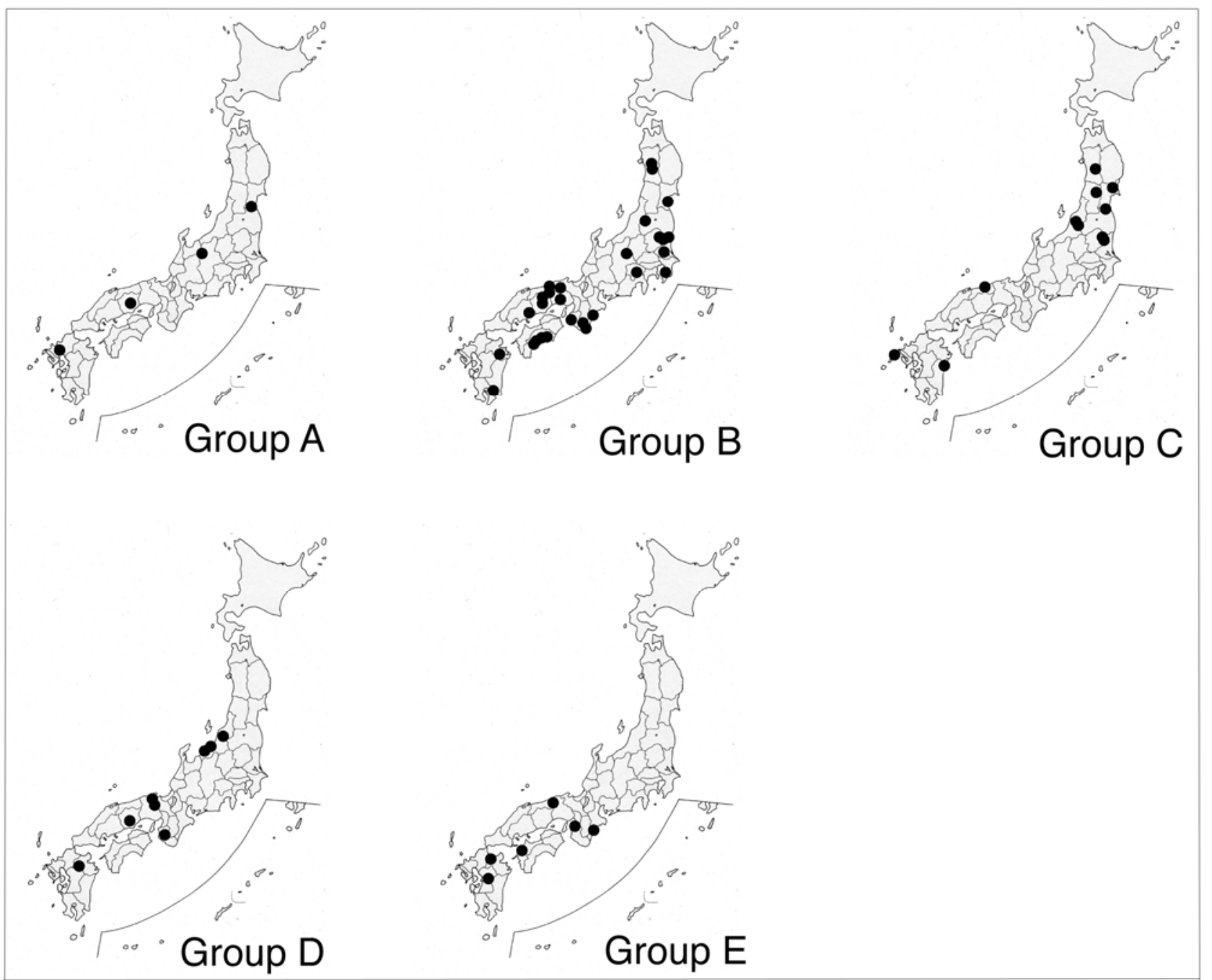

Fig. 1. Geographic distribution of wild adzuki bean (Vigna angularis var. nipponensis) accessions from Japan in disease response groups A-E. Black circles indicate the sampling places where each accession was collected. Groups correspond to the descriptions in Table 1. 
were collected from Japan and Myanmar, whereas those of the other species in group D were collected from several south and southeast Asian countries (Sri Lanka, Myanmar, Thailand, Laos, and the Philippines) (Table 3).

\section{Discussion}

To identify new sources of multiple resistance to $C$. gregata $\mathrm{f}$. sp. adzukicola and F. oxysporum f. sp. adzukicola, we inoculated 252 accessions of Vigna spp. using isolates with specific pathotypes. Fujita et al. (3) screened a total of 36 accessions of $V$. angularis var. nipponensis, V. nakashimae, V. riukiuensis, and V. umbellata (from the TAES collection) by artificial inoculation or a field test using two races (1 and 2) of C. gregata f. sp. adzukicola. They found 16 resistant accessions in $V$. angularis var. nipponensis but not in the other Vigna spp. However, the reactions of these accessions to race 3 were not examined.

Eight disease response groups were detected in this study, of which four were novel. Altogether, 29 accessions from five Vigna spp. (V. angularis var. nipponensis, V. hirtella, V. glabrescens, $V$. minima, and $V$. tenuicaulis) in the section Angulares belonged to group $\mathrm{D}$, with resistance to all of the pathogens. These species are potential sources of multiple resistance genes (1). Crosses between adzuki bean and these species, with the exception of $V$. glabrescens (an allotetraploid derived from $V$. trinervia $\times V$. minima), are reported to produce fertile $\mathrm{F}_{1}$ hybrids (23).

$V$. angularis var. nipponensis showed greater genetic diversity in resistance patterns compared with cultivated adzuki bean (16) and, within this species, three newly designated disease reaction groups $(\mathrm{E}, \mathrm{G}$, and $\mathrm{H})$ were identified. In these three new groups, the reaction to race 1 of $C$. gregata $\mathrm{f}$. sp. adzukicola was opposite to that of race 3 of $F$. oxysporum f. sp. adzukicola. This pattern of reaction was not observed previously in cultivated adzuki bean cultivars or lines (16). On the other hand, the reaction to the former pathogen was the same as that to the latter one in groups A, B, C, and D, and common resistance was explained by pleiotropy of the same gene or a strong linkage between the resistance loci involved in the reaction against the specific pathogens (22). The resistance sources to $F$. oxysporum found in group $\mathrm{E}$ and those to $C$. gregata found in groups $\mathrm{G}$ and $\mathrm{H}$ are considered to be novel. In particular, groups $\mathrm{G}$ (one accession) and $\mathrm{H}$ (two accessions) were found only in $V$. angularis var. nipponensis accessions collected from Laos. Their resistance could be polygenic to the pathogens in Hokkaido (9).

Adzuki bean cultivars in group B and Acc259 in group C were presumed to possess the putative resistance genes Pgal and Pga2, respectively (21; unpublished data) Recently, a specific locus for Pgal resistance to race 1 of $C$. gregata f. sp. adzukicola was mapped to adzuki bean linkage group $3(6,20)$. The availability of molecular markers tightly linked to resistance loci based on genome maps (19) will enable the use of marker-assisted selection in adzuki bean breeding programs. In the near future, inheritance and mapping studies should be carried out on the accessions in the newly detected groups $\mathrm{D}, \mathrm{E}, \mathrm{F}, \mathrm{G}$, and $\mathrm{H}$. In addition, studies to elucidate the mechanism of resistance would be helpful.

Contrary to a prior study (11), in which C. gregata f. sp. adzukicola was avirulent to domesticated $V$. unguiculata, each accession of $V$. unguiculata examined in the present study was designated as group C (domesticated) or E (wild), and was susceptible to at least one of two races of $C$. gregata f. sp. adzukicola. Although the complete host range of $C$. gregata f. sp. adzukicola must be verified, it is likely that the strains of $C$. gregata and $F$. oxysporum used in the present study evolved to be mainly pathogenic to $V$. angularis var. nipponensis. Sources of resistance to host-specific plant pathogens are often found in regions of the greatest differentiation of the host species $(17,25)$. In theory, the host and pathogen coevolved in these regions over a long period of time, and this protracted association led to their diversity. The pathogens used in the present study were isolated from domesticated adzuki bean grown in Hokkaido. The natural distribution of $V$. angularis var. nipponensis includes Japan, the Korean peninsula, China, the northern mountainous region of southeast Asia (Myanmar and Laos), Bhutan, Nepal, and northern India. Further study may find new races of these pathogens from wild adzuki bean growing in regions outside Hokkaido. Examining wild adzuki bean for resistance and the genetic diversity of the pathogens in their natural habitat will ultimately expand researchers' understanding of where these species coevolved.

\section{Acknowledgments}

This research was supported by the Genebank project of the National Institute of Agrobiological Sciences. We thank Y. Koizumi for technical assistance in the greenhouse assays and the Tokachi Agricultural Experiment Station for providing adzuki bean seed.

\section{Literature Cited}

1. Dana, S., and Karmarkar, P. G. 1990. Species relationships in Vigna subgenus Ceratotropis and its implications in breeding. Plant Breed. Rev. 8:19-42.

2. Fujita, S. 2004. Breeding of adzuki bean cultivars resistant to soilborne diseases. PSJ Soilborne Dis. Workshop Rep. 22:88-99. (In Japanese)

3. Fujita, S., Kondo, N., Shimada, H., Murata, K., and Naito, S. 2007. Reevaluation and selection of adzuki beans to breed cultivars resistant to a new race of Phialophora gregata f. sp. adzukicola, the causal agent of adzuki bean brown stem rot (BSR). Breed. Res. 9:87-95. (In Japanese with English summary)

4. Fujita, S., Murata, K., Shimada, H., Aoyama, H., Chiba, I., Matsukawa, I. Shirai, S., Miura, T., Ochi, H., and Kondo, N. 2002. A new adzuki bean variety 'Syumari' with soilborne disease resistance and excellent processing quality. Bull. Hokkaido Pref. Agric. Exp. Stn. 82:31-40. (In Japanese with English summary)

5. Fujita, S., Shimada, H., Murata, K., Shirai, S., Hara, M., Adachi, T., and Chiba, I. 1995. A new BSR-resistant variety 'Kita-no-otome' adzuki bean. Bull. Hokkaido Pref. Agric. Exp. Stn. 68:17-31. (In Japanese with English summary)

6. Han, O. K., Kaga, A., Isemura, T., Wang, X. W., Tomooka, N., and Vaughan, D. A. 2005. A genetic linkage map for azuki bean [Vigna angularis (Willd.) Ohwi \& Ohashi]. Theor. Appl. Genet. 111:1278-1287.

7. Harlan, J. R., and De Wet, J. M. J. 1971. Towards a rational classification of cultivated plants. Taxon 20:509-517.

8. Harrington, T. C., and McNew, D. L. 2003. Phylogenetic analysis places the Phialophora-like anamorph genus Cadophora in the Helotiales. Mycotaxon 87:141-151.

9. Harris M. K. 1975. Allopatric resistance: searching for sources of insect resistance for use in agriculture. Environ. Entomol. 4:661-669.

10. Kitazawa, K., and Yanagita, K. 1989. Fusarium oxysporum Schl. f. sp. adzukicola n. f. sp., a wilt fungus of Phaseolus angularis. Ann. Phytopathol. Soc. Jpn. 55:76-78. (In Japanese with English summary)

11. Kobayashi, K., Yamamoto, H., Negishi, H., and Ogoshi, A. 1991. Formae specialis differentiation of Phialophora gregata from adzuki bean and soybean in Japan. Ann. Phytopathol. Soc. Jpn. 57:225-231.

12. Kondo, N., Fujita, S., Murata, K., and Ogoshi, A. 1998. Detection of two races of Phialophora gregata f. sp. adzukicola, the causal agent of adzuki bean brown stem rots. Plant Dis. 82:928-930.

13. Kondo, N., Kobayashi, Y., Sakuma, F., Fujita, S., and Murata, K. 2002. Regional distribution of two races of Phialophora gregata f. sp. adzukicola the causal agent of adzuki bean brown stem rot, and their genetic diversity in Hokkaido, the northernmost island of Japan. J. Gen. Plant Pathol. 68:284-291.

14. Kondo, N., and Kodama, F. 1989. Fusarium oxysporum f. sp. adzukicola, causal agent of adzuki bean wilt, and detection of three races of the fungus. Ann. Phytopathol. Soc. Jpn. 55:451-457.

15. Kondo, N., Nakazawa, K., Fujita, S., Shimada, H., and Naito, S. 2005. New virulent race of Phialophora gregata f. sp. adzukicola associated with continuous cultivation of adzuki bean cultivar Acc259. J. Gen. Plant Pathol. 71:360-363.

16. Kondo, N., Shimada, H., and Fujita, S. 2009. Screening of cultivated and wild adzuki bean for resistance to race 3 of Cadophora gregata f. $\mathrm{sp}$. adzukicola, cause of brown stem rot. J. Gen. Plant Pathol. 75:181-187.

17. Leppik, E. E. 1970. Gene center of plants as sources of disease resistance. Annu. Rev. Phytopathol. 8:323-344.

18. Narita, T., Akai, J., and Tsuboki, K. 1971. Adzuki brown stem rot and its pathogenic fungus. Plant Prot. 25:353-358. (In Japanese)

19. Somta, P., Kaga, A., Tomooka, N., Kashiwaba, K., Isemura, T., Chaitieng, B., Srinives, P., and Vaughan, D. A. 2006. Development of an interspecific Vigna linkage map between Vigna umbellata (Thunb.) Ohwi \& Ohashi and V. nakashimae (Ohwi) Ohwi \& Ohashi and its use in analysis of bruchid resistance and comparative genomics. Plant Breed. 125:77-84.

20. Suzuki, T., Takeuchi, T., and Shimada, H. 2009. Adzuki bean brown stem rot resistant gene Pgal is identical of very tightly linked to adzuki bean Fusarium wilt resistant gene Foa3. (Abstr.) Jpn. J. Phytopathol. 75:251. (In Japanese)

21. Takeda, A., Suzuki, T., Takeuchi, T., Fujita, S., Shimada, H., Kondo, N., and Naito, S. 2006. Screening of adzuki bean germ plasm for adzuki brown 
stem rot resistance gene using DNA markers. (Abstr.) Jpn. J. Phytopathol. 72:85. (In Japanese)

22. Takeda, A., Suzuki, T., Takeuchi, T., Fujita, S., Shimada, H., Kondo, N., and Naito, S. 2007. Linkage analysis of adzuki bean brown stem rots resistance gene and adzuki bean Fusarium wilt resistance gene. (Abstr.) Jpn. J. Phytopahol. 73:218. (In Japanese)

23. Tomooka N, Kaga A, Isemura T, Vaughan DA. 2011. Vigna. Pages 291-311 in: Wild Crop Relatives: Genomic and Breeding Resources. Legume Crops and Forages. C. Kole, ed. Springer, Heidelberg.

24. Tomooka N., Vaughan, D. A., Maxted, N., and Moss, H. 2002. The Asian Vigna. Genus Vigna subgenus Ceratotropis Genetic Resources. Kluwer Academic Press, The Netherlands.

25. Vavilov, N. I. 1949-1950. The origin, variation, immunity and breeding of cultivated plants. Chron. Bot. 13:1-364. 